\title{
Successful Intracervical Insemination and Characteristics of Anoa (Bubalus sp.) Parturation Behavior in Captivity
}

\author{
Judi $^{a, *}$, T. L. Yusuf ${ }^{b}$, B. Purwantara ${ }^{a}$, D. Sajuthi ${ }^{b}$, M. Agil ${ }^{a}$, J. Manangsang ${ }^{c}$, R. Sudarwatic \\ Y. T. Hastutic ${ }^{c}$ B. Huaso ${ }^{c}$, A. Widianti ${ }^{c}$, \& S. Prastiti \\ ${ }^{a}$ Division of Reproduction and Obstetrics, ${ }^{b}$ Division of Internal Medicine, \\ Department of Veterinary Clinic, Reproduction and Pathology, \\ Faculty of Veterinary Medicine - Bogor Agricultural University \\ Jln. Agatis, Kampus IPB Darmaga, Bogor 16680, Indonesia \\ PT Taman Safari Indonesia, Cisarua, Bogor-Indonesia \\ (Received 01-08-2011; accepted 21-05-2012)
}

\begin{abstract}
ABSTRAK
Anoa, yang merupakan salah satu satwa endemik di Indonesia, populasinya semakin menurun, sehingga saat ini dimasukkan dalam endangered species oleh International Union for Conservation of Nature (IUCN). Penelitian ini bertujuan untuk mengkaji aplikasi teknik inseminasi buatan (IB) pada anoa dan megetahui perilaku proses kelahiran. Penelitian melibatkan 2 anoa jantan dan 5 anoa betina di Taman Safari Indonesia Bogor. Semen dikoleksi menggunakan elektroejakulator, lalu dievaluasi dan diencerkan dalam pengencer Tris-kuning telur. Anoa betina yang estrus setelah disinkronisasi, diinseminasi intraservikal menggunakan semen cair (100 juta/1,0 ml), dalam keadaan teranastesi. Hewan yang tidak estrus melebihi 2-3 siklus setelah IB dianggap bunting, dan dikonfirmasi menggunakan ultrasonografi. Sebagai pembanding, dilakukan USG pada 1 anoa lain yang diduga bunting setelah kawin alam. Hasilnya menunjukkan bahwa 1 dari 4 ekor anoa dikonfirmasi bunting. Lama periode kebuntingan pada anoa adalah 313 hari (hasil IB) dan 324 hari (hasil kawin alam). Proses partus dapat diamati dan dibagi menjadi 3 tahap, dengan durasi setiap tahap adalah 6-8 jam (tahap 1, dikarakterisasi oleh kontraksi abdominal, dan pengeluaran dan perobekan kantong amnion), 30-60 menit (tahap 2, dikarakterisasi oleh pengeluaran fetus), dan 15-180 menit (tahap 3, dikarakterisasi oleh pengeluaran plasenta dan induk memakan plasenta). Disimpulkan bahwa teknik IB dapat diaplikasikan pada anoa di penangkaran dan karakteristik proses partus pada anoa adalah mirip dengan kerbau dan sapi. Namun demikian, pengeluaran anak terjadi pada posisi induk berdiri dan induk memakan plasenta.
\end{abstract}

Kata kunci: anoa, inseminasi buatan, ultrasonografi, kebuntingan, kelahiran

\section{ABSTRACT}

Anoa, which is the endemic animal in Indonesia, its population is unevitably decreasing, therefore anoa included in the list of endangered species by International Union for Conservation of Nature (IUCN). The experiment was aimed to apply the artificial insemination (AI) technique for anoa and to examine their parturition behavior. The experiment involved 2 males and 5 females anoa at Taman Safari Indonesia Bogor. Semen was collected by electroejaculator, then evaluated and diluted in Trisegg yolk extender. The anesthetized estrous females were inseminated intracervically with extended semen (100x106 sperm/1.0 mL). Females which did not show estrous signs during 2-3 cycles after AI were predicted pregnant, and therefore confirmed by ultrasonography. As a comparison, another predicted-pregnant female after natural mating was scanned. The results showed that intracervical AI resulted pregnancy in one female, and the gestation period of anoa was ranged from $313 \mathrm{~d}$ (AI) to $324 \mathrm{~d}$ (natural mating). There were three stages of parturition process was observed: Stage 1 was characterized by the abdominal contraction and amniotic membrane rupture, Stage 2 was characterized by the fetal expulsions, and Stage 3 was characterized by the placental expulsions and ingestion of placenta by the dam. The duration of each stage of parturition was 6-8 $\mathrm{h}$ (stage 1), 30-60 min (stage 2), and 15-180 min (stage 3). It is concluded that AI technique was applicable to anoa in captivity, and the parturation behavior of anoa was comparable to buffalo and cattle. However, the fetal delivery occurred when the dam was in standing position and the dam ingested the placenta.

Key words: anoa, artificial insemination, ultrasonography, pregnancy, parturation 


\section{INTRODUCTION}

Anoa is an endemic animal in Indonesia found in Sulawesi and its offshore islands. There are two species of anoa, the lowland anoa (Bubalus depressicornis Smith, 1827 ) and the mountain anoa (Bubalus quarlesi Ouwens, 1910) (Burton et al., 2005a). The population of anoa in the wild is in rapidly decline, so both of them are classified as endangered by IUCN and included into Appendix I of the CITES (Burton et al., 2005a).

Both species of anoa are vulnerable due to their restricted range of habitat and extinction possibilities from several threats by illegal hunting, habitat loss and fragmentation, and possible natural catastrophes (Burton et al., 2005b). These threats cause the anoa become isolated in small populations in the fragmented habitat or lived in the conservation area that may cause to the loss of genetic diversity and increasing extinction risks (Burton et al., 2005a). Therefore, the management of the anoa population in captivity is important. Unfortunately, until present, anoa breeding efforts in captivity have not been succeed, that might be caused by their aggressivity, solitary, wildness, and monogamy, as well as the limitation of their reproductive biology data.

Several studies have been conducted in many aspects of the anoa, but the study on their reproduction is still limit; they include the sexual behavior (Feer, 1994), taxonomy (Burton et al., 2005a), potency of anoa as a farm animals (Kasim, 2002), semen collection and its characteristics (Judi et al., 2009), and sperm cryopreservation (Judi et al., 2011). However, it has not been reported the application of assisted reproductive techniques (ART) especially on the artificial insemination (AI) and also the behavior during parturation, as essential stages for the success of breeding in anoa in captivity. In fact, this information might be very important to improve their management and handling (the dam and the fetus) during peri-partum period.

The characteristics of anoa behavior are soliter, aggressive, and tend to be monogamus. These characteristics may result in many problems in the future caused by the limitation of population. Therefore, application of ARTs (i.e. AI technique) in anoa is very important. In addition, sperm cryopreservation as a stage of AI program, will be a genetic resource of scarce animal, and furthermore can be used in other ARTs application, i.e. in vitro fertilization and cloning (Holt \& Pickard, 1999; Morrow et al., 2009). The successful of AI application in many wild animals have been reported, for examples in puma and deer (Holt \& Pickard, 1999), African white rhino (Hermes et al., 2009), and llama and zebra (Adams et al., 2009). Application of AI technique in wild animals in captive breeding may prevents inbreeding incidence caused by the lacking of the population or genetic diversity; inbreeding may cause increase the risk of testis development defects with consequent infertility, embryonic loss, and decreases the adaptation capacity (Hold \& Pickard, 1999; Commizoli et al., 2000).

The birth of a healthy calf is basic requirement for the successful of the captive breeding. Therefore, detection of some complications during parturation and helping them as soon as possible are important. Calves from difficult parturations show a clearly increased mortality during the first $24 \mathrm{~h}$ after parturation (Wehrend et al., 2006). Understanding the characteristics behavior of parturation is necessary to improve parturation management. In wild animals, there are technical limitations linked to various anatomy, physiology, and behavior (Commizoli et al., 2000). This experiment was conducted to apply the AI technique for anoa breeding and to study the characteristics of parturation behavior in anoa in captivity.

\section{MATERIALS AND METHODS}

\section{Experimental Animals}

The experiment was conducted in Taman Safari Indonesia Bogor West Java, using 7 anoas: 2 males and 5 females (i.e. $\mathrm{Bu}, \mathrm{Ay}, \mathrm{Ta}, \mathrm{Lu}$, and $\mathrm{Ke}$ ). All anoas were clinically in a good condition and were maintained with standard captive practices. The males were given feed supplements: 6000 IU vitamin A (Vitamin A ${ }^{\circledR}$, PT Kimia Farma - Indonesia) and vitamin B complexes (consisted of $100 \mathrm{mg}$ vit. B1, $200 \mathrm{mg}$ vit. B6, $200 \mathrm{mg}$ vit. B12) and 200 IU vit. E (Neurovit E ${ }^{\circledR}$, PT Kimia Farma-Indonesia) every day starting from 2 mo before experiment. The males were injected with 750 IU of human chorionic gonadothropin (hCG) (Chorulon ${ }^{\circledR}$, Intervet Inc.-Holland) $2 \mathrm{~h}$ before semen collection.

\section{Estrus Synchronization}

Four female anoas were estrous shynchronized by intramuscular single injection of 3.75 mg PGF2- $\alpha$ analog, luprostiol (Prosolvin ${ }^{\circledR}$, Intervet Inc.-Holland) and 500 mg pregnant mare serum gonadothropin (PMSG) (Folligon ${ }^{\circledR}$, Intervet Inc.-Holland). Luprostiol was injected at the luteal phase (day 7-10 after estrous signs were appeared), and PMSG was injected a day before. All animals then were observed for their sexual behavior (i.e. estrous signs) to determine the optimum time for insemination.

\section{Animal Handling}

All experimental anoas were anesthized by intramuscular injection of the combination of ketamine $\mathrm{HCl}$ $(1.5-2.0 \mathrm{mg} / \mathrm{kg}) \quad$ (Ketamil $^{\circledR}$ injection, Illium-Australia) and medetomidine $\mathrm{HCl}\left(50-100 \mu \mathrm{g} / \mathrm{kg}\right.$ ) (Domitor ${ }^{\circledR}$, Orion Pharma-Finland): before semen collection, insemination, or pregnancy diagnosis. Immediately after animal handling, all of them injected with an antidota, atipamezole (250-500 $\mu \mathrm{g} / \mathrm{kg}$ ) (Antisedan ${ }^{\circledR}$, Orion Pharma-Finland) intramuscular.

\section{Semen Collection, Evaluation, and Processing}

Semen was collected from anesthetized animals by using electroejaculator (modified from Paris et al., 2005) connected to an electrostimulator AC $100 \mathrm{~Hz}$ and $1.50 \mathrm{~cm}$ diameter of rectal probe with four circular electrodes (Fujihira FHK-Japan). The probe was lubricated with jelly (KY Lubricating Jelly ${ }^{\circledR}$, PT Johnson \& Johnson-Indonesia) and inserted into the rectum with 
the electrode ventrally oriented in close apposition to the assessory glands. The electroejaculation sequence consisted of six series was separated by 5 -s rest periods. Each stimulus was consisted of three 5-s stimuli at each of voltages $(3,5,7,9,11$, and $12 \mathrm{~V})$.

Ejaculates were evaluated visually for the volume, color, and $\mathrm{pH}$; and microscopically for mass activity, progressive motility, live dead-ratio, sperm concentration, and total sperm abnormality. Only the ejaculates showing more than $50 \%$ progressive motility and $100 \times 10^{6}$ cells $/ \mathrm{ml}$ of sperm concentration were used. Ejaculates were diluted with Tris-egg yolk (20\% egg yolk) medium into $100 \times 10^{6}$ sperm $/ \mathrm{ml}$. Tris buffer $(100$ $\mathrm{ml}$ ) contained $3.649 \mathrm{mg}$ tris (hydroxymethyl) aminomethane (cat. no: 1.08382.0500, Merck KGaA-Germany), $1.70 \mathrm{mg}$ citric acid monohydrate (cat. no: 1.00244.0500, Merck KGaA-Germany), and $1.25 \mathrm{mg}$ D(-)fructose (cat. no: 1.05323.0250, Merck KGaA-Germany); and was supplemented with $1000 \mathrm{IU} / \mathrm{ml}$ penissilin (Penissilin-G Meiji $^{\circledR}$, PT Meiji Indonesia-Indonesia) and $1 \mathrm{mg} / \mathrm{ml}$ streptomycin (Streptomycin sulfate Meiji ${ }^{\circledR}$, PT Meiji Indonesia-Indonesia). Extended semen was then kept in room temperature during preparation of females for AI.

\section{Intraservical Insemination}

The synchronized females $(n=4)$ showing estrous signs were inseminated intracervically (Verberckmoes et al., 2001; Kershaw et al., 2005) using extended semen with insemination dose of $100 \times 10^{6}$ sperm $/ \mathrm{ml}$. Insemination was conducted in approximately 50-60 h after luprostiol injection under anesthetized condition using AI pipette (Minitub GmbH-Germany) commonly used for both sheep and goats. A vaginal speculum was inserted into the vagina to locate os cervix by means of a light source fixed on the speculum, and semen was deposited in the maximum depth of cervical penetration by the pipette (Batista et al., 2009). During insemination, the perineal region of female was lifted for around $5 \mathrm{~min}$ after semen deposition to help the sperm to enter the uterus.

\section{Pregnancy Diagnosis}

One female (Lup) that did not show estrous signs during 2-3 of estrous cycles after insemination was predicted pregnant, and therefore was confirmed by ultrasonography (USG). A transrectal scanning using a 7.5 MHz linear probe (Aloka SSD-500, Aloka Co. Ltd.-Japan) was performed for pregnancy diagnosis under anesthetized condition. Examination was done for around 6 mo after insemination. The active surface of the transducer (where piezoelectric crystals are located) was lubricated with jelly and inserted through anal opening, before progressing cranially along the rectal floor to overlie the reproductive tract (Vyas et al., 2002). The lubricated face of the transducer was pressed firmly towards the ventral rectal wall to ensure the transmission of ultrasound waves through rectal mucosa into pelvic and abdominal viscera. As a comparison, another female (K) that predicted pregnant after 7 mo of natural mating was scanned.

\section{Observation of Parturation Behavior}

Parturation behavior was observed from a distance of 2-5 $\mathrm{m}$ from outside the yard or pen, starting from 6 mo gestation (modified from Wehrend et al., 2006). Observation was done in 2 females positively diagnosed pregnant by USG. The following parameters were documented: feeding behavior, the udder and teats swelling, vulva swelling, excretion of cervical mucus, restlessness, lying down and getting up, vocalization, abdominal contraction, kyphosis position, and also expulsion of amniotic sac, fetus, and placenta. Observation was carried out during the day time, from 07.00 to 17.00 o'clock. When the behavior changed that indicate the partum would be occurred soon, observation was done $24 \mathrm{~h}$ per d. During parturation process, observation focused on the behavior in each stage of parturation. The behavior was recorded and classified into 3 stages: the first stage (preparation/cervical dilatation), the second stage (fetal delivery), and the third stage (placental delivery) (Senger, 2005; Wehrend et al., 2006).

\section{RESULTS AND DISCUSSION}

\section{Semen Characteristics}

The characteristics of anoa fresh semen were fairly good as shown in Table 1. However, some semen variables showed lower number compared to buffalo and bull semen. Similar results also reported in many others wild mammals, for examples in Sumateran rhino (Dicerorhinus sumatrensis) (O'brien \& Roth, 2000) and Indian tiger (Jayaprakash et al., 2001). Ejaculate of Sumateran rhino collected using by recovery postcoital technique have $60 \%$ of motility, $70 \%$ of sperm viability, $24.6 \mathrm{million} / \mathrm{ml}$ of sperm concentration, and $60 \%$ of total abnormality (O'brien \& Roth, 2000). In Indian tiger (Panthera pardus), ejacuate collected using by eletroejaculator have motility of $57.05 \pm 16.96 \%$, sperm concentration of $55.78 \pm 38.67$ million $/ \mathrm{ml}$, dan total abnormality of 29.1\%-84.7\% (Jayaprakash et al., 2001).

Table 1. The characteristics of anoa semen and the comparation with the buffalo semen

\begin{tabular}{lcc}
\hline Variables & Anoa $(\mathrm{n}=5)$ & Buffalo $^{\mathrm{a}, \mathrm{b}}$ \\
\hline Color & white - & white to milky \\
& transparence & white \\
Volume $(\mathrm{ml})$ & $1.02 \pm 0.28$ & $2-8$ \\
$\mathrm{pH}$ & $6.93 \pm 0.19$ & $6.7-7.5$ \\
Mass activity & 0 & 2.33 \\
Progressive motility (\%) & $52.5 \pm 18.91$ & $>70$ \\
Live-dead ratio (\%) & $67.48 \pm 8.24$ & $>70$ \\
Sperm consentration & $263.33 \pm 105.06$ & $600-1,200$ \\
(x 106/ml) & & \\
Total abnormality & $31.86 \pm 3.72$ & 10 \\
\hline
\end{tabular}

Note: ${ }^{a, b}$ Herdis (1998); Sansone et al. (2000). 


\section{Successful of AI Application}

Present study showed that AI application in anoa resulted in one out of four female was pregnant and produce a live male calf. However, the efficiency was still low (25\% of pregnancy rate, PR and 8.0 of service per conception, S/C) (Table 2). Confirmation of the pregnant female using USG at around 6 mo of gestation showed the eye balls, sculls, ribs, and other organs of the fetuses, as well as the placentomes (Figure 1).

The results of this study suggested that AI application in anoa was still inefficient compared to the farm animals. In cattle, AI application is efficient if the PR is higher than $75 \%$ and $\mathrm{S} / \mathrm{C}$ is $1.2-2.0$ (Toelihere, 1993). Verberckmoes et al. (2001) reported that intracervical insemination in sheep resulted in 56\%-75\% PR, but Batista et al. (2009) showed only $42.8 \%$ PR. In fallow deer, intracervical insemination resulted PR of $62.9 \%$ PR (using frozen semen) to $76.3 \%$ (using fresh semen) (Jabbour et al., 1993). However, AI application in many others wild mammals resulted low pregnancy rate. For examples, transcervical AI in African white rhino (Ceratotherium simum) resulted in a pregnancy of two females and produced a healthy offspring (Hermes et al., 2009), and in South American camelids resulted in 39\% (frozen semen) to 51\% PR (fresh semen) (Adams et al., 2009).

Successful AI application in wild mammals established by understanding of species-characteristics of the anatomy and physiology of reproduction, stress management, sperm quality and quantity, oocytes quality, dates of insemination, semen deposition, gametes trans- portation system, and early embryonic loss (Toelihere, 1993; Durrant, 2009; Hermes et al., 2009; Morrow et al., 2009). The lower pregnancy rate found in this experiment might have been due to insufficient sperm quality in terms of low progressive motility $(52.5 \%)$ and high level of total sperm abnormality $(31.8 \%)$ that was reported previously (Judi et al., 2009). The quantity of total sperm number $\left(100 \times 10^{6} \mathrm{sperm} / \mathrm{ml}\right)$ may below the minimum threshold required to achieve fertilization in this species. Hermes et al. (2009) reported that AI in African white rhino with $135 \times 10^{6}$ motile sperm was failed, but when the dose was increased up to $500 \times 10^{6}$ motile sperm resulted a pregnancy. In sheep, the maximum depth of cervical penetration during intracervical insemination was affected by both cervical grade of canalis cervicalis and the dates of estrous phase, and those factors may affect the result of AI application (Kershaw et al., 2005). Unfortunately, the optimum mating time and the anatomy of the cervix uteri of anoa have not yet been understood. Therefore, to improve the pregnancy rate in anoa in captivity, more information about the reproductive biology, animal handling, determine of the optimum mating time, sperm preservation and cryopreservation, and also insemination dose and semen deposition are required.

\section{The Length of Gestation Period}

Present result showed that the gestation length of anoa was $313 \mathrm{~d}$ (resulted of AI) and $324 \mathrm{~d}$ (resulted of natural mating) (Table 2). The result is longer than that

Table 2. The result of AI application and the length of gestation period of anoa in Taman Safari Indonesia Bogor

\begin{tabular}{|c|c|c|c|c|c|}
\hline Dams & $\begin{array}{l}\text { Number of AI or } \\
\text { natural mating }\end{array}$ & $\begin{array}{l}\text { Pregnancy } \\
(+/-)\end{array}$ & $\begin{array}{l}\text { Parturation } \\
\text { (dates) }\end{array}$ & $\begin{array}{c}\text { Gestation period } \\
\text { (d) }\end{array}$ & Sex of fetuses \\
\hline $\mathrm{Bu}$ & 2 & $(-)$ & - & -- & - \\
\hline Ay & 2 & $(-)$ & -- & -- & -- \\
\hline Ta & 3 & $(-)$ & -- & -- & -- \\
\hline $\mathrm{Lu}$ & 1 (June 4, 2009) & $(+)$ & (Apr 13, 2010) & 313 & Male \\
\hline $\left.\mathrm{Ke}^{*}\right)$ & 1 (May 25, 2009) & $(+)$ & (Apr 14, 2010) & 324 & Female \\
\hline
\end{tabular}

Note: *) natural mating; $\mathrm{Bu}, \mathrm{Ay}, \mathrm{Ta}, \mathrm{Lu}$, and Ke are 5 female anoas used in the experiment.

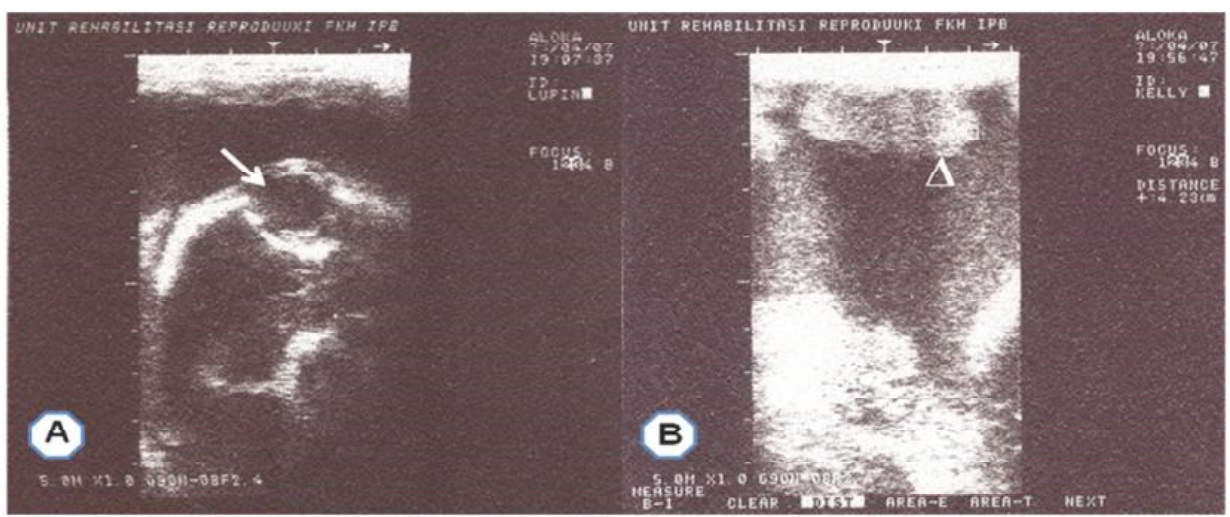

Figure 1. Ultrasonogram of 6 mo pregnant uterus anoa $(A)$ showed an eye ball $(\rightarrow)$, and 7 mo pregnant uterus anoa $(B)$ showed a 4 -cm of placentome $(\Delta)$. 
of reported by Kasim (2002) previously, 275-315 d. The gestation period of anoa was comparable to swamp buffalo (310 d) and mare (330 d), and therefore, it was longer than in cattle $(278 \mathrm{~d})$ and in goat $(150 \mathrm{~d})$ (Jainudeen \& Hafez, 2000). The length of gestation period of the primipara $(\mathrm{K})$ with a female fetus (324 d) was longer than the multipara (L) with a male fetus ( $313 \mathrm{~d})$.

Pregnancy period is variable in breeds, species, and individual within species, because of genetic factors, parity, age, nutrition, litter size, and sex of the fetus (Toelihere, 1993; Hutchin et al., 1996; Jainudeen \& Hafez, 2000). Hutchin et al. (1996) reported that male fetuses may extend the gestation length (for example in cattle and sheep), and the increased the fetal number will shorten it (for example in cattle, canidae, and mice). The date of conception during breeding season also affect the length of gestation period of red deer (Cervus elaphus), may be related with the feed intake and quality (Scott et al., 2008).

\section{Characteristics of Parturation Process}

At around 7 mo of gestation, occasionally in the morning, the brownish mucus was appeared hanged out from the vulva, and the color changed to reddish-dark brown at around 9 mo of gestation. At that time also appeared swelling of the teats and labia of the vulva. A week toward parturation, the mucus was expelled more frequently and voluminous, the dams was occasionally laying down inside and the feet were stretched, and aparted from her group. During 1-2 d toward parturation, the dams showed restlessness (getting up and lay-

Table 3. The characteristics of parturation behavior in anoa in captivity

\begin{tabular}{|c|c|c|}
\hline Stages of parturation & Behavioral elements & Duration \\
\hline $\begin{array}{l}\text { Stage } 1 \\
\text { (preparation) }\end{array}$ & $\begin{array}{l}\text { - cervical mucus was excreted, hang out from the vulva } \\
\text { - abdominal contraction, more frequently and powerful when the am- } \\
\text { niotic sac was expelled } \\
\text { - occasionally kyphosis position and vocalization } \\
\text { - expulsion of fetal foreleg (in the amniotic sac), } \\
\text { - the dams showed restlessness (getting up and lying down, more } \\
\text { movement) } \\
\text { - amniotic membrane was ruptured }\end{array}$ & $\begin{array}{l}\text { - abdominal contrac- } \\
\text { tion: } 6 \text { to } 8 \mathrm{~h} \\
\text { - amniotic membrane } \\
\text { expulsion: } 2 \mathrm{~h}\end{array}$ \\
\hline $\begin{array}{l}\text { Stage } 2 \\
\text { (fetal delivery) }\end{array}$ & $\begin{array}{l}\text { - the calves was visible in the rima vulvae } \\
\text { - the fetal position was antero-dorsal (fetal vertebrae in upper site) to } \\
\text { delivery canal } \\
\text { - fetal delivery, the dam was in standing position }\end{array}$ & $30 \mathrm{~min}(\mathrm{~L})$ to $1 \mathrm{~h}(\mathrm{~K})$ \\
\hline $\begin{array}{l}\text { Stage } 3 \\
\text { (placental delivery) }\end{array}$ & $\begin{array}{l}\text { - the dams licked the fetuses } \\
\text { - expulsion of placenta, by the maternal contraction (K) or pulled out } \\
\text { by the dam (L) } \\
\text { - the dams ate the placenta immediately after delivered }\end{array}$ & $15 \mathrm{~min}(\mathrm{~L})$ to $3 \mathrm{~h}(\mathrm{~K})$ \\
\hline
\end{tabular}
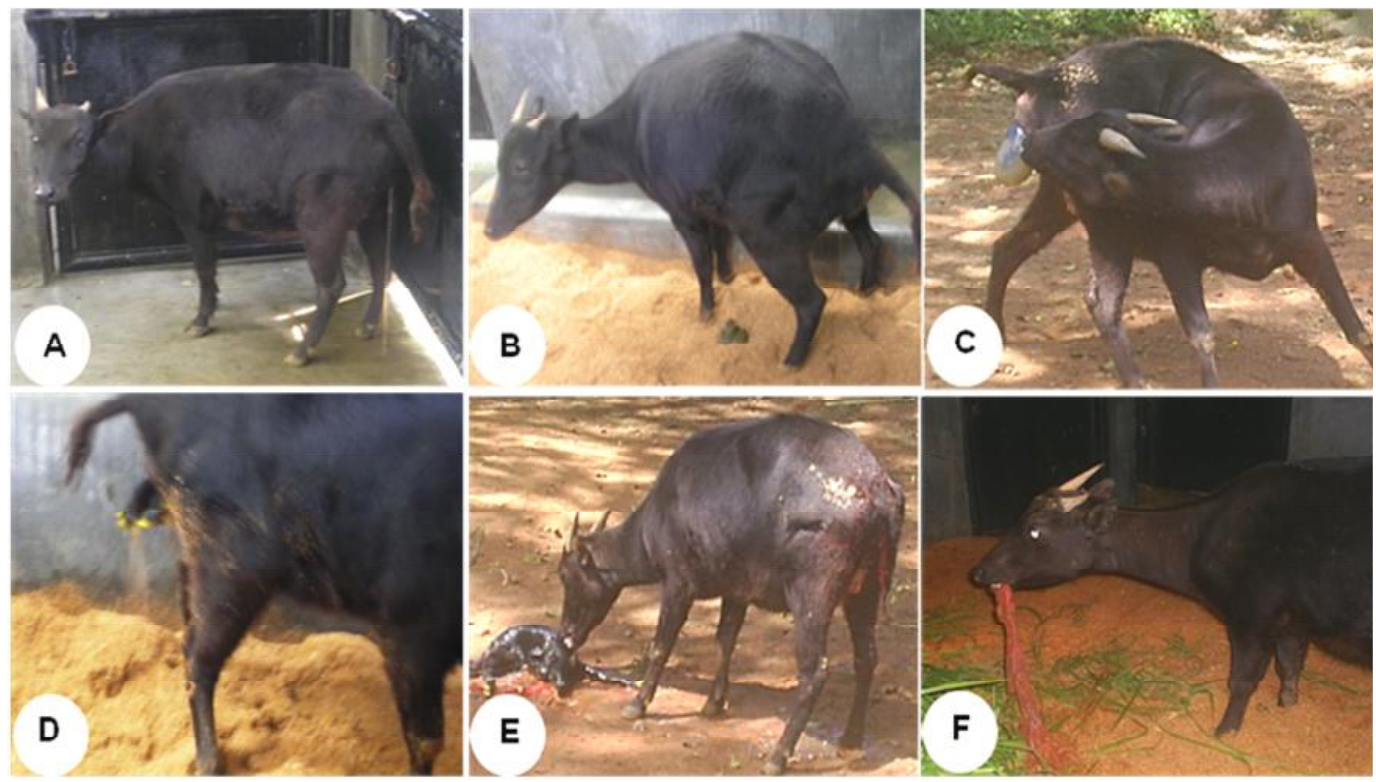

Figure 2. The serial photos described the parturation process in anoa and its behavior observed in captivity; showed the cervical mucus hanged out from vulva (A), abdominal contraction and kyphosis (B), expulsion of the amnotic membrane (C), expulsion of both fetal foreleg (D), the dam was licking the fetus (E) and eating the placenta (F). 
ing down, more movement), decreasing of appetite, and more vocalization. These behavior are common in the last second semester of pregnancy (Jainudeen \& Hafez, 2000), particularly in pasturing ungulates (WodzickaTomaszewska et al., 1991).

Entering to the first stage of parturation (preparation stage), the anoa showed abdominal contraction, moving around the pens, and expulsion and rupture of amniotic membrane (Table 3, Figure 2). The second stage of parturation (fetal delivery) was characterized by the appearance of the calf in the rima vulvae, and fetal expulsion. The last stage of parturation (placental delivery) was characterized by expulsion and delivery of placenta, and the dams lick the fetus and eat the placenta. Duration of each stage of parturation was 6-8 $\mathrm{h}$ in the first stage, 30-60 $\mathrm{min}$ in the second stage, and 15-180 min in the third stage. Fetal expulsion occurred while the dams were in standing position. One female (L) pulled out the placenta which was hanging out from the vulva with her mouth and then ate it, whereas another female $(\mathrm{K})$ ate the placenta that was already fell to the floor. This maybe an instinct behavior in wild to escape from natural catastrophes, which was still exhibit in anoa lived in captivity.

The duration of parturation varied among species, and affected by many factors such as fetal weigh, fetal position, litter size, the sex of fetus, parity, breeds and species, and pelvic size of the dams (Toelihere, 1993; Jainudeen \& Hafez, 2000). In cattle and buffalo, the duration of the first, second, and third stages of parturation were 2-6 $\mathrm{h}, 0.5-1 \mathrm{~h}$ and $8-12 \mathrm{~h}$, respectively; whereas, in sheep were 2-6 h, 0.5-2 $\mathrm{h}$ and 0.5-8.0 h, respectively (Jainudeen \& Hafez, 2000). The present result suggested that duration of parturation in the anoa was comparable to buffalo and cattle.

\section{CONCLUSION}

AI technique was applicable for anoa breeding in captivity. The gestation period of anoa was about 313 and $324 \mathrm{~d}$. Gestation period and characteristics of parturation behavior of anoa were comparable to buffalo and cattle. The fetal delivery occurred when the dam was in standing position and the dam ingested the placenta.

\section{ACKNOWLEDGEMENT}

We wish to acknowledge the management of PT Taman Safari Indonesia Bogor, (West Java) for providing the animals, and special thanks to the medical team of animal hospital and the keepers for their technical assistances.

\section{REFERENCES}

Adams, G. P., M. H. Ratto, C. W. Collins, \& D. R. Bergfelt. 2009. Artificial insemination in South American camelids and wild equids. Theriogenology 71: 166-175. http://dx.doi. org/10.1016/j.theriogenology.2008.09.005.

Batista, M., T. Nino, D. Alamo, N. Castro, M. Santana, F. Gonzalez, F. Cabrera, \& A. Gracia. 2009. Successful artificial insemination using semen frozen and stored by an ultrafreezer in the Majorera goat breed. Theriogenology 71:
1307-1315. http://dx.doi.org/10.1016/j.theriogenology.2008. 12.024 .

Burton, J., S. Hedges, \& A. H. Mustari. 2005a. The taxonomic status, distribution and conservation of the lowland anoa (Bubalus depressicornis) and mountain anoa (Bubalus quarlesi). Mammal Rev 35: 25-50. http://dx.doi.org/10.1111/ j.1365-2907.2005.00048.x

Burton, J., A. H. Mustari, \& A. A. MacDonald. 2005b. Status dan rekomendasi: konservasi in situ anoa (Bubalus sp.) dan implikasinya terhadap konservasi ex situ. Buletin Konservasi Alam 5: 35-39.

Commizoli, P., P. Mermillod, \& R. Mauget. 2000. Reproductive biotechnologies for endangered mammalian species. Reprod. Nutr. Dev. 40: 493-505. http://dx.doi.org/10.1051/ rnd:2000113

Durrant, B. S. 2009. The importance and potential of artificial insemination in CANDES (companion animals, non-domestic, endangered species). Theriogenology 71: 113-122. http://dx.doi.org/10.1016/j.theriogenology.2008.09.004

Feer, F. 1994. Observations ethologiques sur Bubalus (Anoa) quarlesi ouwens, 1910 (Ruminantia, Bovidae) en Captivite. Z. Saugetierkunde 59: 139-152.

Herdis. 1998. Metode Pemberian Gliserol dan Lama Ekuilibrasi pada Proses Pembekuan Semen Kerbau Lumpur. Tesis. Sekolah Pascasarjana, Institut Pertanian Bogor.

Hermes, R., F. Goritz, J. Saragusty, E. Sos, V. Molnar, C. E. Reid, F. Schwarzenberger, \& T. B. Hildebrandt. 2009. First successful artificial insemination with frozen-thawed semen in Rhinoceros. Theriogenology 71: 393-399. http:// dx.doi.org/10.1016/j.theriogenology.2008.10.008

Holt, W. V. \& A. R. Pickard. 1999. Role of reproductive technologies and genetic resource banks in animal concervation. Rev Reprod 4: 143-150. http://dx.doi.org/10.1530/ ror.0.0040143

Hutchins, M., P. Thomas, \& C. S. Asa. 1996. Pregnancy and Parturition in Captive Mammals. In: D. E. Kleiman, M. E. Allen, K. V. Thompson, \& S. Lumpkin (Eds). Wild Mammals in Captivity. The University of Chicago Press, Chicago USA. pp. 468-496.

Jabbour, H. N., F. A. Veldhuizen, G. Green, \& G. W. Asher. 1993. Endocrine responses and conception rates in fallow deer (Dama dama) following oestrous synchronization and cervical insemination with fresh or frozen-thawed spermatozoa. J. Reprod. Fertil. 98: 495-502. http://dx.doi. org/10.1530/jrf.0.0980495

Jainudeen, M. R. \& E. S. E. Hafez. 2000. Gestational, Prenatal Physiology, and Parturition. In: E. S. E. Hafez \& B. Hafez (Eds). Reproduction in Farm Animals. $7^{\text {th }}$ ed. Lippincott Wiliams and Wilkins, Baltimore, USA. p.140-155.

Jayaprakash, D., S. B. Patil, M. N. Kumar, K. C. Majumdar, \& S. Shivaji. 2001. Semen characteristics of the captive Indian leopard (Panthera pardus). J. Androl. 22: 25-33.

Judi, T. L. Yusuf, B. Purwantara, D. Sajuthi, S. Mulyono, \& J. Manangsang. 2009. Biometri organ reproduksi bagian luar dan karakteristik ejakulat anoa (Bubalus sp.) yang dikoleksi menggunakan elektroejakulator setelah diinjeksi hCG. Med. Pet. 32: 1-11.

Judi, T. L. Yusuf, B. Purwantara, D. Sajuthi, \& M. Agil. 2011. Karakteristik plasma semen dan keberhasilan kriopreservasi semen anoa (Bubalus Sp.) yang dikoleksi menggunakan elektroejakulator. JITV 16: 40-47.

Kasim, K. 2002. Potensi anoa (Bubalus depressicornis dan Bubalus quarlesi) sebagai alternatif satwa budidaya dalam mengatasi kepunahannya. Disertasi. Program Pascasarjana Institut Pertanian Bogor, Bogor.

Kershaw, C. M., M. Khalid, M. R. McGowan, K. Ingram, S. Leethongdee, G. Wax, \& R. J. Scaramuzzi. 2005. The anatomy of the sheep cervix and its influence on the transcervical passage of an inseminating pipette into the uter- 
ine lumen. Theriogenology 64: 1225-1235. http://dx.doi. org/10.1016/j.theriogenology.2005.02.017.

Morrow, C. J., L. M. Penfold, \& B. A. Wolfe. 2009. Artificial insemination in deer and non-domestic bovids. Theriogenology 71: 149-165. http://dx.doi.org/10.1016/j.theriogenology .2008.09.001.

O'brien, J. K. \& T. L. Roth. 2000. Postcoital sperm recovery and cryopreservation in Sumatran rhinoceros (Dicerorhinus sumatrensis) and aplication to gamete rescue in the African black rhinoceros (Diceros bicornis). J. Reprod. Fertil. 118: 263-271. http://dx.doi.org/10.1530/jrf.0.1180263

Paris, D. B. B. P., D. A. Taggart, G. Shaw, P. D. Temple-Smith, \& M. B. Renfree. 2005. Birth of pouch young after artificial insemination in the Tammar wallaby (Macropus eugenii). Biol Reprod 72: 451-459. http://dx.doi.org/10.1095/biolreprod.104.033282.

Sansone, G., M. J. F. Nastri, A. Fabbrocini. 2000. Storage of buffalo (Bubalus bubalis) semen. Anim Reprod Sci. 62: 55-76.

Scott, I. C., G. W. Asher, J. A. Archer, \& R. P. Littlejohn. 2008. The effect of conception date on gestation length of red deer (Cervus elaphus). Anim. Reprod. Sci. 109: 206-217. http://dx.doi.org/10.1016/j.anireprosci.2007.11.025.
Senger, P. L. 2005. Pathways to Pregnancy and Parturition. Current Conception Inc, Washington.

Toelihere, M. R. 1993. Inseminasi Buatan pada Ternak. CV Angkasa, Bandung.

Verberckmoes, S., I. de Pauw, A. Van Soom, G. Vanroose, H. Laevens, \& A. de Kruif. 2001. Cervical isemination in sheep. Vlaams Diergeneeskundig Tijdschrift 70: 475-480.

Vyas, S., G. N. Purohit, P. K. Pareek, \& M. S. Sahani. 2002. Ultrasonographic imaging to monitor early pregnancy in the camel (Camelus dromedarius). Revue Élev. Méd. vét. Pays trop. 55: 241-245.

Wehrend, A., E. Hofmann, K. Failing, \& H. Bostedt. 2006. Behaviour during the first stage of labour in cattle: influence of parity and dystocia. Appl. Anim. Behavior. Sci. 100: 164170. http://dx.doi.org/10.1016/j.applanim.2005.11.008.

Wodzicka-Tomaszewska, M, I. K. Sutama, I. G. Putu, \& T. D. Chaniago. 1991. Reproduksi, Tingkah Laku, dan Reproduksi Ternak di Indonesia. PT Gramedia Pustaka Utama, Jakarta. 